\title{
Concentrations of Metals in Tissues of Fish from the Věstonice Reservoir
}

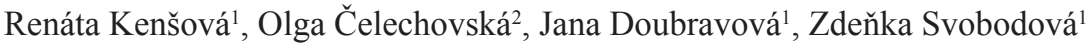 \\ ${ }^{1}$ Department of Veterinary Public Health and Toxicology, \\ Faculty of Veterinary Hygiene and Ecology \\ ${ }^{2}$ Department of Biophysics and Biochemistry, Faculty of Veterinary Hygiene and Ecology, \\ University of Veterinary and Pharmaceutical Sciences in Brno, Czech Republic
}

Received May 12, 2009

Accepted October 21, 2009

\begin{abstract}
The aim of the present work was to compare the distribution of selected metals in tissues of several fish species caught in the Věstonice reservoir. The hygienic quality of fish meat was assessed with respect to the mercury concentration. A total of 35 fish of the following species were caught: carp (Cyprinus carpio), bream (Abramis brama), asp (Aspius aspius), pikeperch (Sander lucioperca) and pike (Esox lucius). Samples of muscle, liver (hepatopancreas), kidney, gonads and gills were analyzed. $\mathrm{Hg}, \mathrm{Pb}, \mathrm{Cd}, \mathrm{Cu}, \mathrm{Zn}$ and $\mathrm{Cr}$ concentrations in fish tissues were determined by the AAS. The results showed that different metals differ in their affinity to different fish tissues (e.g. $\mathrm{Cu}$ - liver, $\mathrm{Cd}$ - kidney). Mercury concentrations along the food chain increase, i.e. higher mercury concentrations are found in predatory fish. Contrary to mercury, cadmium and lead concentrations do not show any increases along the fish part of food chain in surface water ecosystems. In predatory fish, lower concentrations of these metals were found than in nonpredatory fish species. Differences in concentrations between ovaria and testes were found only in $\mathrm{Cu}$ and $\mathrm{Zn}$. To evaluate possible health risks of mercury concentrations for consumers, the risk index was calculated and maximum admissible amounts of muscle meat for consumption were determined. The results confirmed good hygienic quality of market-ready fish from the Věstonice reservoir.
\end{abstract}

Predatory fish, non-predatory fish, heavy metals, AAS, risk index

The rising living standards of human population take their toll in increasing loads to the environment with various contaminating substances that occur naturally at very low concentrations, or do not naturally occur at all. Besides metal manufacturing and processing, the sources of environmental metal contamination include industrial waste products, the burning of fossil fuels, and the use of metals by consumers. The increase in metal concentrations in the environment is further enhanced by their poor degradability resulting in metal accumulation in the soil, water sediments and the food chain (Svobodová et al. 1987).

As the final link of the food chain in the aquatic environment, fish are an important indicator of contamination by a number of substances, including metals (Svobodová et al. 1996). Moreover, toxic metal concentrations in fish are monitored also in terms of food safety (Svobodová et al. 2004). First and foremost, the most closely monitored potentially toxic metals include mercury followed by cadmium and lead. In recent years, food safety has been a priority in EU member states. Hence, the large number of regulations targeting veterinary food hygiene that are being adopted mainly by the European Food Safety Authority (EFSA) and other organisations. At present, hygienic limits are determined by the highest acceptable levels of contaminants in foodstuffs in the Commission Regulation 1881/2006/EC as amended and Decrees 68/2005 Sb. and 305/2004 Sb. of the Ministry of Health. As far as fish as food animals are concerned, the main attention is focused on economically important species (carp, rainbow trout) (Svobodová et al. 2004), and fish from dam reservoirs. This is because dam reservoirs accumulate contaminants from large areas.

Address for correspondence:

Mgr. Renáta Kenšová

University of Veterinary and Pharmaceutical Sciences

Faculty of Veterinary Hygiene and Ecology

Department of Veterinary Public Health and Toxicology

Palackého 1-3, 61242 Brno, Czech Republic
Phone.: +420 541562780

Fax: +420 541562790

E-mail: rkensova@vfu.cz

http://www.vfu.cz/acta-vet/actavet.htm 
In the study reported here, attention was focused on metal concentrations in marketready fish from the Věstonice reservoir.

The aims of the present study were:

- to compare levels of selected metals in individual tissues of different fish species from the Věstonice reservoir

- to assess the metal loads in fish from the reservoir

- to assess the hygienic quality of market-ready fish from the site investigated.

\section{Materials and Methods}

The aim of the work was to determine concentrations of total mercury, lead, cadmium, copper, zinc and chromium in tissues of predatory and non-predatory market-ready fish from the Věstonice reservoir. The Věstonice reservoir is the central body of water of the three reservoirs (Fig. 1). The reservoir is a part of the DyjeSvratka Rivers water management system, and it is operated by the company Povodí Moravy, a.s. The reservoir was put into operation in 1980. Its purpose is to accumulate water to ensure continuous minimum flow rates, to provide water for agricultural irrigation and for the industry, for inundation of floodplain forests, to supply water to a network of canals, minor watercourses and spring areas. The reservoir also serves to decrease flow rates during floods, is used by anglers and for the generation of electricity in the local hydraulic power plant. The total reservoir capacity is 34 million $\mathrm{m}^{3}$ with the flooded area of 1.033 ha. Fish from this reservoir are obtained both by recreational and commercial fishing and are used for human consumption purposes.

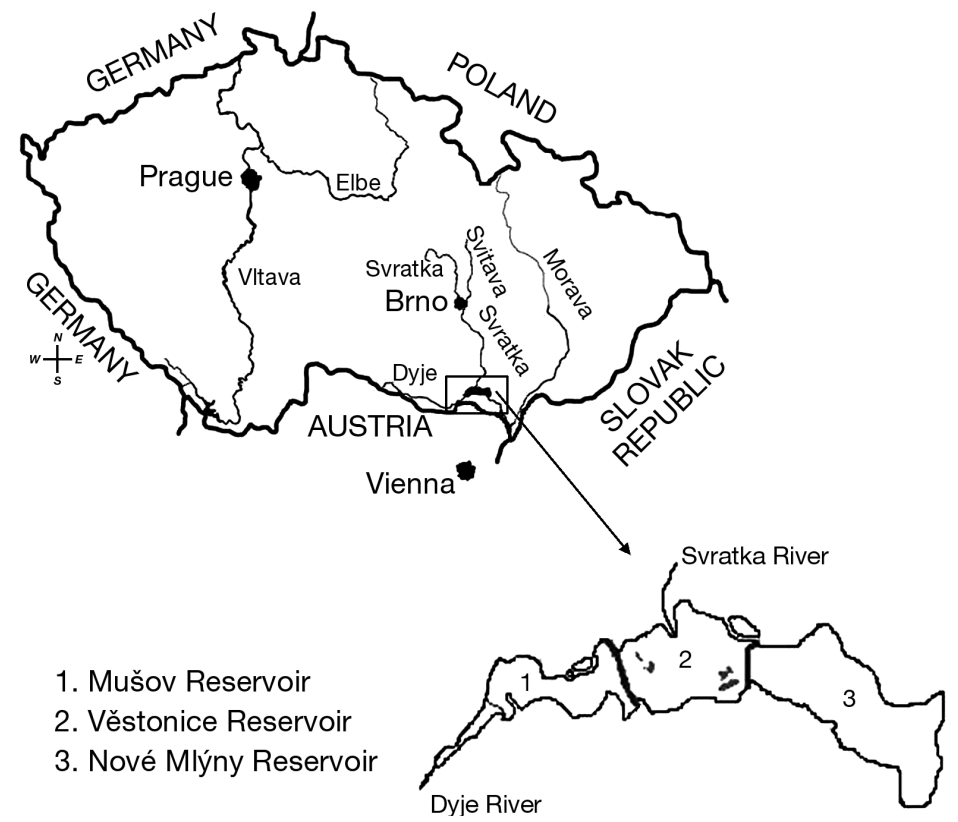

Fig. 1. Map of the Czech Republic showing the study site location

The fish for analysis were caught in the autumn of 2005. A total of 35 fish of 5 species were caught and analyzed. The fish species included asp (Aspius aspius), pike (Esox lucius), pikeperch (Sander lucioperca), carp (Cyprinus carpio) and bream (Abramis brama). Characteristics of the examined fish are presented in Table 1. The weight was determined using SARTORIUS 1712 calibrated balances and the age was determined from scales using MEOFLEX RI 21 P. All were market-ready fish. Heavy metals were analyzed in muscle, liver (hepatopancreas), kidney, gonads and gills.

Analytical methods

Only glass laboratory equipment and supplies were used to handle the samples. Before determination of metals by atomic absorption spectrometry (AAS), tissues were mineralized by nitric acid and hydrogen peroxide in 
Table 1. Characteristics of fish

\begin{tabular}{|c|c|c|c|c|}
\hline Fish species & Number of fish & $\begin{array}{l}\text { Weight (kg) } \\
(\text { mean } \pm \text { SD) }\end{array}$ & Sex & $\begin{array}{c}\text { Mean age } \\
(\min -\max )\end{array}$ \\
\hline Asp & 3 & $1.58 \pm 0.41$ & $2 \hat{\jmath}, 1 q$ & $5+(5+-6+)$ \\
\hline Pike & 3 & $2.35 \pm 0.39$ & $1 \hat{0}, 2 \%$ & $5+(4+-6+)$ \\
\hline Pikeperch & 7 & $2.20 \pm 1.09$ & $5 \hat{\jmath}, 2+$ & $4+(3+-6+)$ \\
\hline Carp & 6 & $2.67 \pm 0.53$ & $5 \hat{0}, 1+$ & $5+(3+-7+)$ \\
\hline Bream & 16 & $1.26 \pm 0.41$ & $10 \hat{0}, 69$ & $6+(3+-8+)$ \\
\hline
\end{tabular}

laboratory autoclaves with microwave heating (Uniclever, Plasmatronica Poland, ETHOS SEL, Milestone Italy).

All determinations by AAS were made using the Z-5000 spectrometer (Perkin Elmer, USA). Cadmium, lead, chromium and copper levels were determined by electrothermal atomization AAS, and zinc concentrations were determined by flame AAS. The instrument parameters were set according to the manufacturer's recommendations.

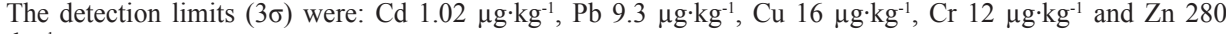
$\mu \mathrm{g} \cdot \mathrm{kg}^{-1}$.

Single-purpose atomic absorption spectrophotometer AMA 254 (Altec s.r.o., CZ) with the detection limit of $0.01 \mathrm{ng} \mathrm{Hg}$ was used to determine total mercury concentrations in individual fish tissues. The instrument is intended for direct mercury determinations in liquid and solid samples without chemical pre-treatment of samples (mineralization, etc.). Samples were decomposed in oxygen flow at an increased temperature and mercury was trapped by amalgamation on gold, from which mercury was released by heating in the subsequent step and carried by oxygen flow to the measuring cuvette.

Metal concentrations in fish tissues are given in $\mathrm{mg} \cdot \mathrm{kg}^{-1}$ wet weight.

Validation and statistical evaluation

The method's validity and accuracy were tested using samples of reference materials BCR No 278 (muscle tissue), NRC TORT-2 (Lobster Hepatopancreas), NCR DORM-2 (Dogfish Muscle) and IAEA MA-B-3/(TM) (fish homogenate).

Statistical evaluation of results was performed using Unistat 5.1 software. Descriptive characteristics, i.e. the arithmetic mean (mean), standard deviation (SD) and the standard error of the mean (SEM) were calculated for each set as part of the statistical data analysis. The significance of differences between the sets was evaluated using ANOVA parametric methods and Tukey test for mutual comparison of individual set pairs.

Health hazard evaluation

Health hazards were evaluated based on mercury concentrations found in muscle tissue regarding mercury as the most important risk factor in fish consumption.

The risk index was calculated according to Kannan et al. (1998) using a reference dose (RfD) for total $\mathrm{Hg}$ ( $0.3 \mathrm{mg} \cdot \mathrm{kg}^{-1}$ body weight per day) set by the US EPA.

To determine the maximum admissible intake of fish meat, the tolerable weekly intake limit (PTWI) of $1.6 \mu \mathrm{g}$ of methylmercury per kg body weight per week was used (WHO 1990). This evaluation was based on the fact that methylmercury in freshwater fish muscle makes up about $80-100 \%$ of total mercury contained there (Hous erová et al. 2006; Maršálek et al. 2005; Maršálek et al. 2007; Kružíková et al. 2008). In calculation of the maximum admissible muscle consumption, $100 \%$ methylmercury of total mercury was used. Calculation was done for two groups of consumers with the average weight of the person considered to be $70 \mathrm{~kg}$.

\section{Results and Discussion}

Statistical evaluation of results did not show any dependence of metal concentrations on fish weight, age or sex. For that reason, the above variables were not taken into account in the processing of the data obtained. Svobodová et al. (1987) pointed out a relationship between $\mathrm{Hg}$ concentrations and fish weight. Our data were close to significance at the level of $P<0.05 \mathrm{Hg}$ concentration in the muscle, liver and kidney in dependence on fish age and weight. The fact that the relationship was below the level of significance might be due to insufficient age and weight differences between individual analyzed fish.

\section{Mercury}

Total mercury concentrations in tissues of analyzed fish species are shown in Fig. 2. It follows from the results obtained that the highest mercury concentrations were found in fish of predatory species. From among non-predatory fish species, the lowest mercury concentrations were found in carp. Statistical evaluation of mercury concentrations in muscle of different fish species showed a significant difference $(P<0.01)$ between the carp and predatory fish species (asp, pike, pikeperch), and between asp and bream, and pike and pikeperch. A significant difference $(P<0.01)$ of $\mathrm{Hg}$ concentrations in the liver was also 


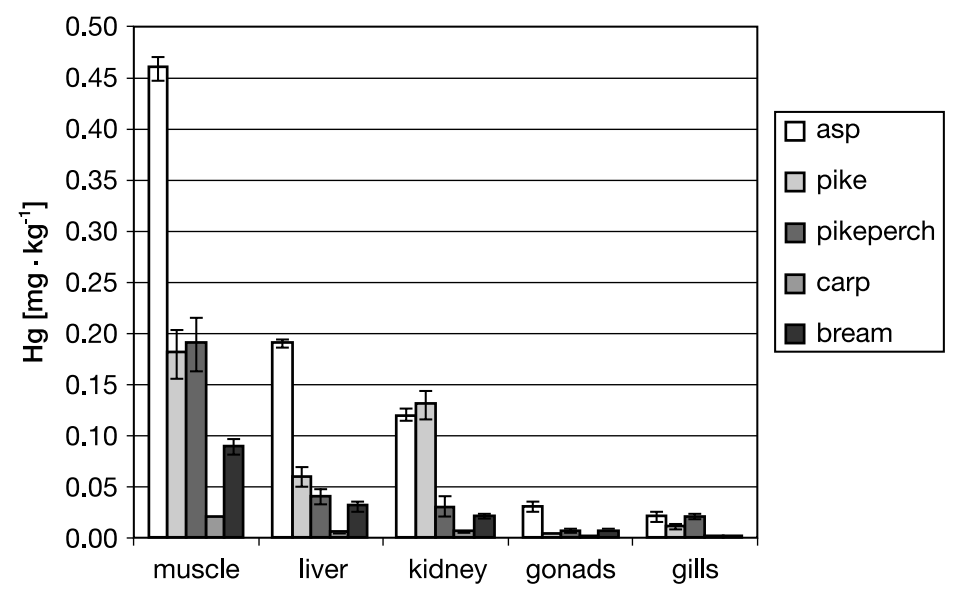

Fig. 2. Mercury concentrations in different fish tissues (mean $\pm \mathrm{SEM}$ )

found between the carp and predatory fish species, and between the asp and the pike and pikeperch. A significant difference $(P<0.01)$ of $\mathrm{Hg}$ concentrations in gonads was found between the asp and other fish species.

Many authors have noted higher mercury concentrations in predatory fish species (Maršálek et al. 2006; Svobodová et al. 1996; Marrugo-Negrete et al. 2008; Lacerda et al. 1994). The mercury burden in predatory fish is greater. Because of poor mercury biodegradability in body tissues, $\mathrm{Hg}$ concentrations increase with the higher position of the species in the food chain (Svobodová et al. 1996). Predatory fish, particularly older (6-12 years of age) and heavier individuals, may serve as a suitable indicator of mercury contamination in the given biotope (Cibulka et al. 1991). From among non-predatory fish species, the lowest mercury concentrations were found in the carp. Carp come from a pond environment and are introduced to the reservoir at the age of 2-3 years, whereas fish of other species live in that environment from their birth. The pond environment is considered less contaminated with mercury (Čelechovská et al. 2007).

A comparison of mercury distribution through different fish tissues showed the highest concentrations in muscle tissue; the lowest concentrations were found in the gills (asp, bream) and gonads (other fish species). According to our results, the highest mercury concentrations are found in muscle tissues, the liver and the kidney. A significant difference $(P<0.01)$ in mercury concentrations between muscle and other tissues was found in all of the analyzed fish species. Most of the analyzed species had significantly higher $(P<0.01)$ mercury concentrations in the liver and kidney compared to mercury concentrations in the gonads and gills. Mercury concentrations in the ovaria and testes were comparable, therefore are given under the heading of gonads.

Similar results of mercury distribution have also been reported by other authors, e.g., Svobodová et al. (2002); Čelechovská et al. (2007) and Has-Schön et al. (2008). According to Staniskiene et al. (2006), the distribution of metals in fish tissues depends on the fish species. The distribution of mercury accumulated in muscles and internal organs of fish depends, among others, on the degree of contamination of the locality monitored. Havelková et al. (2008) demonstrated that in contaminated locations, total mercury concentrations in the liver are significantly higher compared to muscle tissue. On the other hand, mercury concentrations in muscle tissues are usually higher than $\mathrm{Hg}$ concentrations in the liver of fish from uncontaminated locations. The highest mercury concentrations in the fish analyzed in 
our study were found in the muscle tissue, which suggests that the Verstonice reservoir is not significantly contaminated with mercury. Research by Kružíková et al. (2008) focused on the amount of total mercury and methylmercury in the muscle tissue of fish from major rivers of the Czech Republic. For example, the study included Dyje and Svratka rivers that may represent an important source of contamination for the Věstonice reservoir. Their results revealed that the values assessed in both rivers were significantly lower compared to the values detected in the Věstonice reservoir. This observation suggests that these rivers are not the only source of mercury in the Věstonice reservoir.

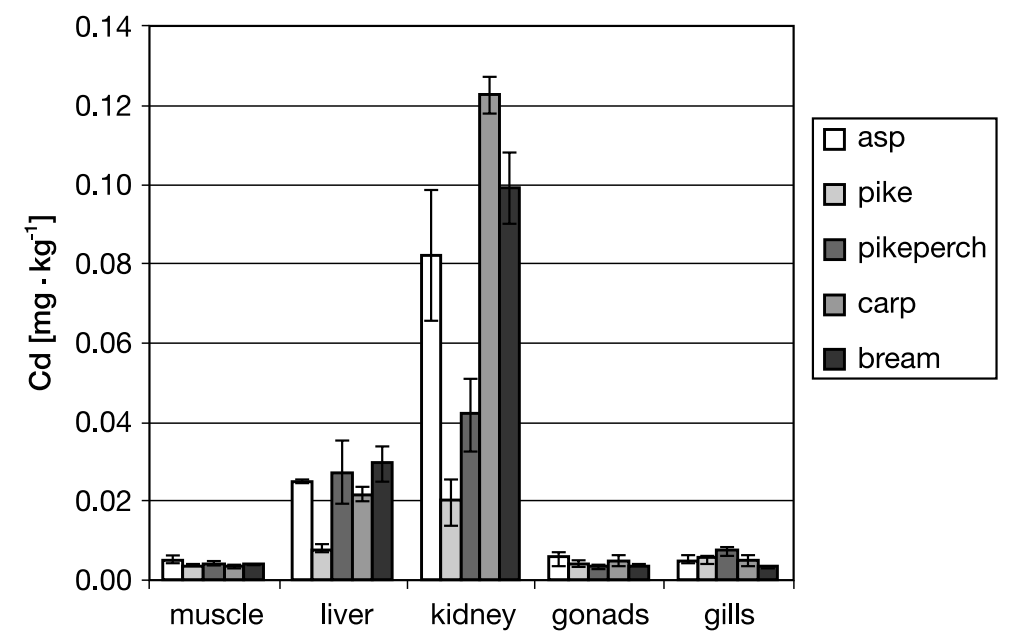

Fig. 3. Cadmium concentrations in different fish tissues (mean $\pm \mathrm{SEM}$ )

Cadmium

Cadmium concentrations in the tissue of different fish species are shown in Fig. 3. Evidently, higher cadmium concentrations in the kidney were mostly found in non-predatory fish species. From among predatory species, the highest concentrations were found in the asp. Statistical evaluation of cadmium concentrations in different fish species showed a significant difference $(P<0.01)$ in kidney concentrations between predatory fish species (pike and asp) and non-predatory fish species (carp, bream). Cadmium concentrations in other tissues were comparable in all the fish species analyzed.

Contrary to mercury, cadmium concentrations do not show any increases along the food chain in surface water ecosystems. For that reason zooplankton, and in particular zoobenthos, are much better bioindicators of contamination (Svobodová et al. 1996). In fact, in predatory fish lower concentrations of cadmium are sometimes found than in nonpredatory fish species. The highest and lowest concentrations were found in the carp and the pike, respectively. It can be explained by the fact that cadmium is mostly accumulated in zooplankton and especially in zoobenthos, which make up the trophic basis of the nonpredatory fish species analyzed.

Comparison of cadmium distribution in different tissues of the analyzed fish showed the highest concentrations in the kidney; the lowest concentrations were found in the muscle (carp, pike and pikeperch) and gills (asp and bream). A significant $(P<0.001)$ difference between cadmium concentrations in the kidney and other tissues was demonstrated in all of the analyzed fish species (with the exception of liver in pikeperch). It follows from Fig. 3 that the liver ranks second with respect to cadmium concentrations. In the bream and the 
carp, a significant difference $(P<0.01)$ was recorded between cadmium concentrations in the liver and in other tissues (muscle, gonads and gills). Cadmium concentrations in the ovaria and testes were comparable and therefore the values are given under the same heading of gonads.

Our results show that the organs of the highest cadmium deposits are the kidney and the liver. The same results were also obtained by some other authors (Čelechovská et al. 2007; Svobodová et al. 2002; Has-Schön et al. 2008). Cadmium has a very long elimination half-life, and thus it gets accumulated in large amounts in parenchymatose tissues (Cornelis et al. 2005). The results correspond to the situation in which $60 \%$ of cadmium intake is deposited in the kidney and liver (Velíšek 2002).

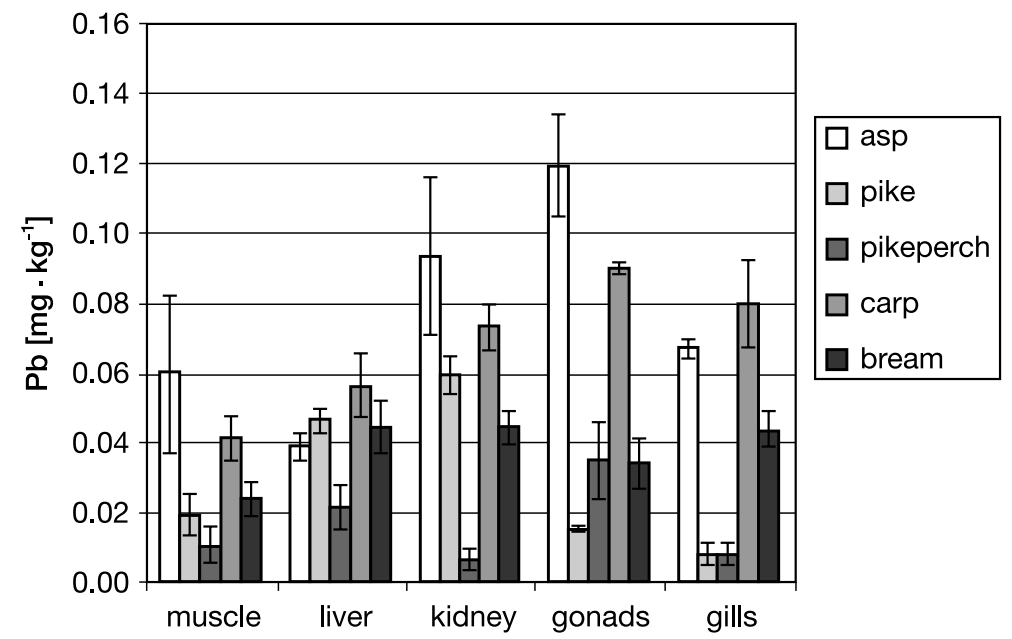

Fig. 4. Lead concentrations in different fish tissues (mean \pm SEM)

\section{Lead}

Lead concentrations in the tissue of the analyzed fish species are shown in Fig. 4. The results show that it is difficult to clearly identify any species-related differences in lead concentrations. The highest lead concentrations were found in tissues of asp (muscle, kidney, gonads) and carp (liver, gills). The lowest lead concentrations were found in all of pikeperch tissues and in pike gonads. Statistical evaluation of lead concentrations in different fish species showed a significant difference $(P<0.01)$ in kidney concentrations between the pikeperch and other fish species. A significant difference $(P<0.01)$ in gonad concentrations was demonstrated between asp and other fish species with the exception of carp. A significant difference $(P<0.01)$ in gill concentrations was found between carp and other fish species with the exception of asp. No significant inter-species differences were found in lead concentrations between muscle tissue and the liver.

It was established that lead concentrations, same as cadmium and contrary to mercury concentrations, do not increase along the food chain in surface water ecosystems. Svobodová et al. (1996) even noted a tendency towards lower lead concentrations in fish tissues along the food chain. They found the highest lead concentrations in zooplankton and zoobenthos, which are the trophic basis for non-predatory fish.

It follows from the comparison of lead concentrations in different tissues that lead distribution in the fish organism is not uniform. Lead concentrations in the ovaria and testes were comparable and therefore the respective values are given under the same heading 
of gonads. The highest lead concentrations were found in the gonads (asp, carp) and the kidney (asp, carp, pike). The lowest concentrations differed according to fish species (e.g. in the kidney, gills and muscle of pikeperch). A significant difference $(P<0.01)$ was found in the pike between the following tissues: kidney - gills, gonads, liver - gills, gonads.

Our results cannot be used to unequivocally identify the target organ of lead deposition. A number of authors (Čelechovská et al. 2007; Has-Schön et al. 2008) believe that the target organ of lead deposition is the kidney. The same conclusions were reached in the present study only when lead concentrations in the kidney were compared to those found in the muscle and liver.

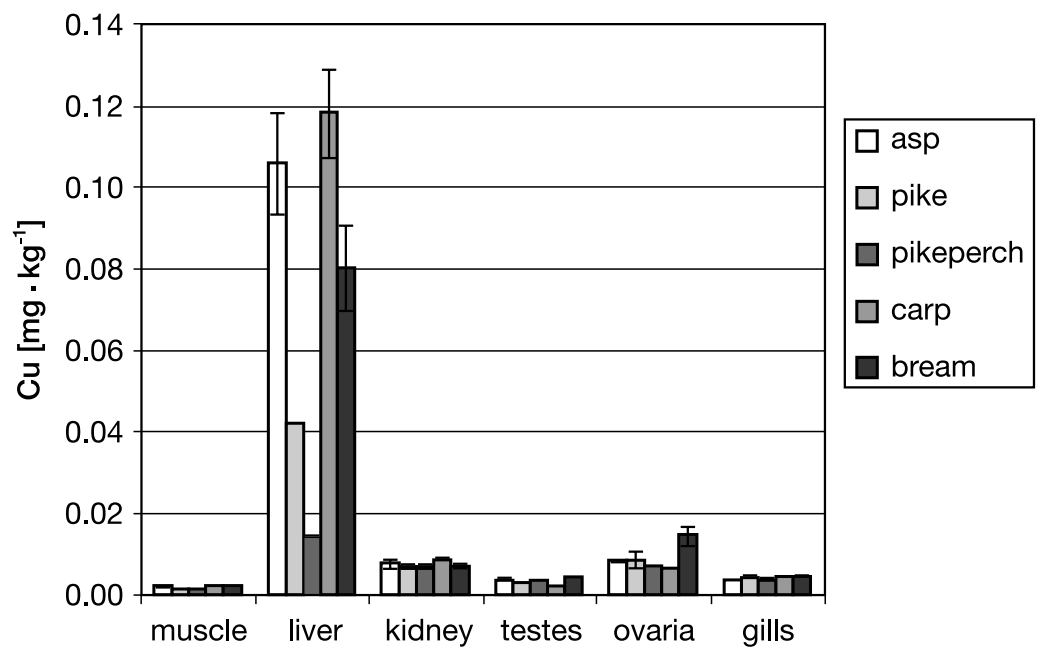

Fig. 5. Copper concentrations in different fish tissues (mean \pm SEM)

\section{Copper}

Copper concentrations in tissue of the analyzed fish species are shown in Fig. 5. Copper concentrations in all tissues with the exception of the liver were comparable in all the fish species. With respect to the liver (hepatopancreas) concentrations, the fish species ranked as follows: asp $>$ carp $>$ bream $>$ pike $>$ pikeperch. Significant differences $(P<0.01)$ were found between pikeperch and other fish species with the exception of pike, and also between pike and asp. In fish gonads, a dependence of copper concentrations on sex was observed. A significant difference $(P<0.05)$ was observed between ovaria and testes in all the fish species. A significant difference in copper concentration $(P<0.01)$ was found in testes between carp and bream.

Comparison of copper distribution in different tissues of the analyzed fish clearly showed the highest concentrations in the liver followed by ovaria and kidney; the lowest concentrations were found in muscle tissues. In all analyzed fish species, a significant difference $(P<0.01)$ was observed between copper concentrations in the liver and other tissues.

Our results show that liver is the organ of copper deposition. Similar results have also been reported by other authors, e.g., Tepe et al. (2008) and Has-Schön et al. (2008). Copper is an inherent part of a number of enzymatic systems localized in the liver, and its high concentrations in this organ are therefore a logical consequence (Bártík and Piskač 1974). A high enzymatic activity is also shown in the ovaria. Similarly to the findings of Svobodová et al. (2002), higher copper concentrations were found in female gonads. 


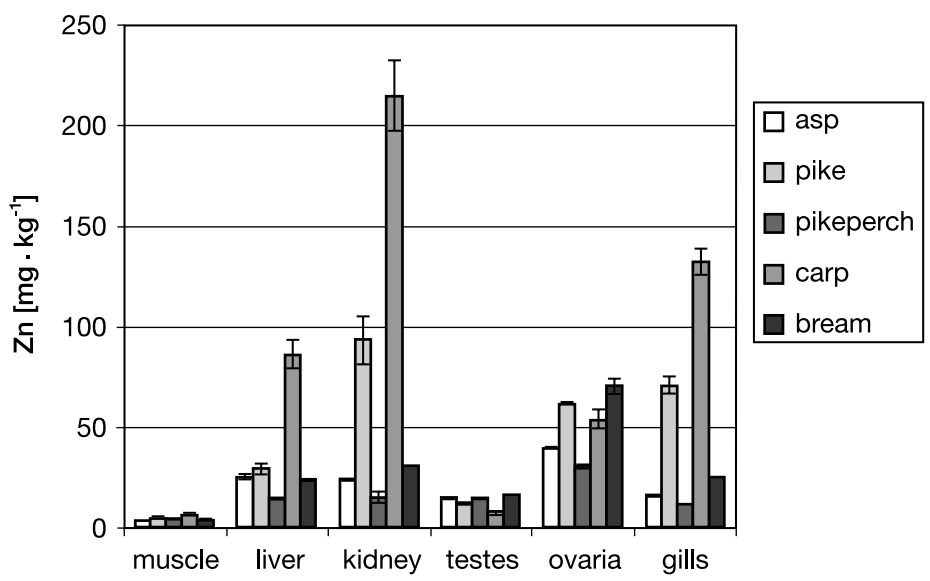

Fig. 6. Zinc concentrations in different fish tissues (mean $\pm \mathrm{SEM}$ )

Zinc

Zinc concentrations in the tissues of analyzed fish are shown in Fig. 6. The highest zinc concentrations were found in carp (muscle, liver, kidney and gills) and bream (gonads). The lowest concentrations were ascertained in pikeperch (liver, kidney, ovaria and gills). The lowest zinc concentrations in muscle tissue were found in asp. Our results indicate that zinc concentrations in non-predatory fish species are higher than those in predatory fish species. A significant difference $(P<0.01)$ of zinc concentrations in muscle was demonstrated in all cases between carp and other fish species with the exception of the pike muscle concentrations.

Comparison of zinc distribution in different fish tissues showed that its highest concentrations were in the liver (carp, pike), ovaria (pike, carp and bream) and the gills (pike, carp). The lowest zinc concentrations found were in the muscle tissue. A significant difference $(P<0.01)$ in $\mathrm{Zn}$ concentrations between muscle tissues and other organs was observed in asp, pikeperch and bream.

In fish gonads, a dependence of zinc concentrations on sex was observed. A significant difference $(P<0.01)$ was observed between ovaria and testes in all the analyzed fish species. Higher $\mathrm{Zn}$ and $\mathrm{Cu}$ concentrations in the ovaria than in the testes were noted by Seymore et al. (1996). The same conclusion regarding zinc concentration in different tissues was also reported by other authors, e.g. Has-Schön et al. (2008). Significantly higher concentrations $(P<0.01)$ of $\mathrm{Cu}$ and $\mathrm{Zn}$ in the kidney compared to other organs were reported by Rehwoldt et al. (1976) and Svobodová et al. (2002). Higher zinc concentrations have also been found in the liver, kidney and ovaria. Zinc forms an integral part of many enzymatic systems. In view of the enzymatic activity, this finding is not surprising because zinc is the cofactor of a number of enzymes.

\section{Chromium}

Chromium concentrations in tissue of the analyzed fish species are shown in Fig. 7. Higher chromium concentrations were observed in non-predatory fish. The highest concentrations were found in bream and carp (muscle, liver and gills). The highest kidney and gonad concentrations were found in carp and asp, respectively. Chromium concentrations in the ovaria and testes were comparable and therefore the values are given under the same heading of gonads. Significant differences $(P<0.01)$ in $\mathrm{Cr}$ concentrations between different fish species were observed in, e.g., the muscle (bream vs. predatory species, i.e. pike and 


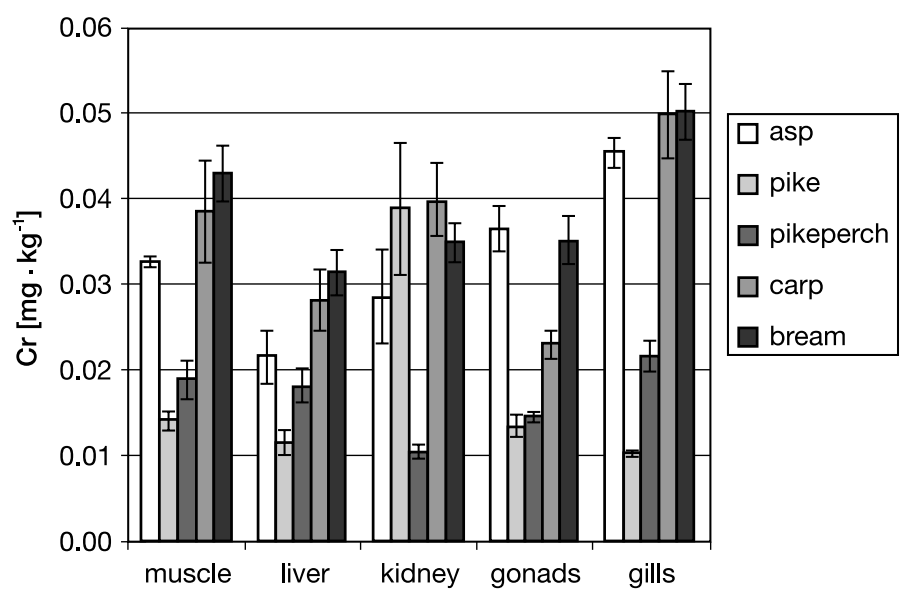

Fig. 7. Chromium concentrations in different fish tissues (mean $\pm \mathrm{SEM}$ )

pikeperch), the liver (bream vs. pike), the kidney (pikeperch vs. the rest of the analyzed fish species).

Chromium distribution in the body is uniform (Fig. 7). Similarly to zinc, higher chromium concentrations were found in the gills for which chromium has a strong affinity. Similar results have also been reported by Svobodová et al. (2002). The order of carp organs according to reported chromium concentrations was: spleen $>$ gills $>$ muscle. A number of authors believe that the entry point for metals in fish are the gills, where toxic metals are accumulated mainly in the initial stage of exposure. For that reason the gills can be particularly suitable as a bioindicator of water contamination with chromium and aluminium (Jezierska and Witeska 2001).

Assessment of health risks associated with consumption of fish from the Věstonice reservoir

Most often, the limiting factor of hygienic quality of freshwater fish is mercury. Potential health hazard caused by mercury in fish from the Věstonice reservoir was evaluated according to risk index calculation by Kannan et al. (1998).

The average consumption rate of freshwater fish in the Czech Republic is $1.4 \mathrm{~kg}$ per person per year (Ministry of Agriculture 2008) in standard consumer family. Some anglers and their families (fishermen's families) in whom higher intakes of fish (up to $10 \mathrm{~kg}$ per person) can be expected, are exceptions (Berka 1998).

The calculated risk index values are given in Table 2 . The risk index values calculated for a standard consumer family are low, in fact several times lower than the risk index of 1. The indices for fishermen's families in the case of predatory fish are 2 to 5 times lower than the risk index of 1 , and in the case of non-predatory fish approximately 1 to 2 orders of magnitude lower that the risk index of 1 .

Calculating admissible amounts of fish muscle tissue for consumption

To determine the admissible amounts of fish muscle that may be consumed, the provisional tolerable weekly intake limit (PTWI) of $1.6 \mu \mathrm{g} \cdot \mathrm{kg}^{-1}$ body weight and specific mercury concentrations in muscle tissues of different fish species were used.

The calculated maximum admissible amounts of muscle meat acceptable for consumption are given in Table 2. 
Table 2. Results of the health risk assessment

\begin{tabular}{|l|c|c|c|}
\hline \multirow{2}{*}{ Fish species } & \multicolumn{2}{|c|}{ Risk index* } & \multirow{2}{*}{$\begin{array}{c}\text { Fish consumption } \\
\text { limits } \\
\text { nys }\end{array}$} \\
\cline { 2 - 3 } & $\begin{array}{c}\text { Standard consumer } \\
\text { family }\end{array}$ & Fisherman's family & 0.27 \\
\hline Asp & 0.075 & 0.53 & 0.61 \\
\hline Pike & 0.034 & 0.24 & 0.60 \\
\hline Pikeperch & 0.034 & 0.24 & 3.84 \\
\hline Carp & 0.005 & 0.04 & 1.25 \\
\hline Bream & 0.016 & 0.12 & \\
\hline
\end{tabular}

* Risk index lower than 1 presents a low risk for the consumer
Comparison of metal concentration and hygienic limits

As mentioned above, much attention is paid to mercury, lead and cadmium contamination in fish in the EC legislation. Commission Regulation (EC) $1881 / 2006$ therefore set the maximum levels of these substances, namely, $0.5 \mathrm{mg}$ $\mathrm{Hg} \mathrm{kg}^{-1}$ fresh weight for fish muscle meat and fishery products or, $1.0 \mathrm{mg} \cdot \mathrm{kg}^{-1}$ for some selected species (e.g. eel, pike, sturgeon); $0.3 \mathrm{mg} \mathrm{Pb} \cdot \mathrm{kg}^{-1}$ and $0.05 \mathrm{mg} \mathrm{Cd} \cdot \mathrm{kg}^{-1}$ or $0.1 \mathrm{mg} \mathrm{Cd} \cdot \mathrm{kg}^{-1}$ in some selected fish species. The hygienic limits for concentrations of mercury, lead or cadmium in muscle meat were not exceeded. The other metals are currently not limited by the EC.

The results of hygienic risk assessment of metal contamination confirmed good hygienic quality of fish from the Věstonice reservoir.

\section{Obsah kovů v tkáních ryb z údolní nádrže Věstonice}

Cílem předkládané práce bylo porovnat distribuci vybraných kovů v tkáních různých druhů ryb odlovených z údolní nádrže Věstonice a zhodnotit hygienickou kvalitu masa těchto ryb z hlediska obsahu rtuti. Odloveno bylo 35 kusů ryb následujících druhů: kapr obecný (Cyprinus carpio), cejn velký (Abramis brama), bolen dravý (Aspius aspius), candát obecný (Sander lucioperca) a štika obecná (Esox lucius). Analyzovány byly vzorky svaloviny, jater (hepatopankreas), ledvin, gonád a žaber. Ve tkáních ryb byl sledován obsah $\mathrm{Hg}$ pomocí jednoúčelového atomového absorpčního spektrofotometru AMA 254 a obsah $\mathrm{Pb}, \mathrm{Cd}, \mathrm{Cu}, \mathrm{Zn}$ a Cr pomocí AAS. Výsledky ukázaly, že různé kovy mají rozdílnou afinitu k různým tkáním ryb (např. $\mathrm{Cu}$ - játra, $\mathrm{Cd}$ - ledviny). Koncentrace rtuti vzrůstá s potravním řetězcem, tzn. že vyšší koncentrace rtuti jsou pozorovány u dravých ryb. Kadmium a olovo se na rozdíl od rtuti nezvyšují se vzrůstajícím stupněm potravního řetězce v ekosystémech povrchových vod. U dravých ryb je pozorována dokonce nižší koncentrace těchto kovů než u nedravých ryb. Rozdílné hodnoty obsahu sledovaných kovů v jikrách a mlíčí byly zaznamenány pouze u $\mathrm{Cu}$ a $\mathrm{Zn}$. U rtuti bylo provedeno hodnocení možného zdravotního rizika pro konzumenty stanovením indexu rizika a bylo stanoveno maximální prrijatelné množství svaloviny ke konzumaci. Výsledky potvrdily dobrou hygienickou kvalitu tržních ryb z Věstonické nádrže.

\section{Acknowledgement}

The study was a part of the MSM project 6215712402 "Veterinary Aspects of Food Safety and Food Quality".

\section{References}

Bártík M, Piskač A 1974: Veterinární toxikologie (Veterinary toxicology). SZN Praha, 304 p.

Berka R 1998: Sladkovodní ryby - co s nimi dál (Fresh water fish - what next). Výživa a potraviny 53: 106-107

Cibulka J, Domažlická E, Kozák J, Kubizňáková J, Mader P, Machálek E, Maňkovská B, Musil J, Pařizek J, Píša J, Pohunková H, Reisnerová H, Svobodová Z 1991: Pohyb olova, kadmia a rtuti v biosféře (Movement of lead, cadmium and mercury in the biosphere). Academia Praha, p: 83-104

Cornelis R, Caruso J, Crews H, Heumann K 2005: Handbook of Elemental Speciation II. Species in the enviroment, food, medicine and occupatial health. Wiley, Chichestr England, 768 p.

Čelechovská O, Svobodová Z, Žlábek V, Macharáčková B 2007: Distribution of metals in tissues of the common carp (Cyprinus carpio L.). Acta Vet Brno 76: S93-S100

Has-Schön E, Bogut I, Kralik G, Bogut S, Horvatić J, Čačić I 2008: Heavy metal concentration in fish tissues inhabiting waters of "Buško Blato" reservoir (Bosna and Herzegovina). Environ Monit Assess 144:15-22 
Havelková M, Dušek L, Némethová D, Poleszczuk G, Svobodová Z 2008: Comparison of mercury distribution between liver and muscle - a biomonitoring of fish from lightly and heavily contaminated localities. Sensors 8: 4095-4109

Houserová P, Kubán̆ V, Spurný P, Habarta P 2006: Determination of total mercury and mercury species in fish and aquatic ecosystems of Moravian rivers. Vet Med-Czech 51: 101-110

Jezierska B, Witeska M 2001: Metal toxicity to fish. Wyd. Akademii Podlaskiej, Siedlce, 318 p.

Kannan K, Smith RG, Lee RF, Windom HL, Heitmuller PT, Macauley JM, Summers JK 1998: Distribution of total mercury and methyl mercury in water, sediment and fish from South Florida estuaries. Arch Environ Contam Toxicol 34: 109-118

Kružíková K, Randák T, Kenšová R, Kroupová H, Leontovyčová D, Svobodová Z 2008: Mercury and methylmercury concentrations in muscle tissue of fish caught in major rivers of the Czech Republic. Acta Vet Brno 77: 637-643

Lacerda L, Bidone E, Guimaraes A, Pfeiffer W 1994: Mercury concentrations in fish from the ItacaiúnasParauapebas river system, Carajás region, Amazon. Annais da Academia Brasilieria de Ciências 66: 373-379

Marrugo-Negrete J, Verbel JO, Ceballos EL, Benitez LN 2008: Total mercury and methylmercury concentration in fish from the Mojana region of Columbia. Environ Geochem Health 30: 21-30

Ministerstvo zemědělství (Ministry of Agriculture) 2008: Situační a výhledová zpráva. Ryby (Situation and Outlook Report. Fish). October 2008: 1-43

Maršálek P, Svobodová Z, Randák T 2006: Total mercury and methylmercury contamination in fish from various sites along the Elbe river. Acta Vet Brno 75: 579-585

Maršálek P, Svobodová Z, Randák T 2007: The content of total mercury and methylmercury in common carp from selected Czech ponds. Aquac Int 15: 299-304

Maršálek P, Svobodová Z, Randák T, Švehla J 2005: Total mercury and methylmercury contamination of fish from the Skalka reservoir: a case study. Acta Vet Brno 74: 427-434

Rehwoldt R, Karimian-Teherani D, Altmann H 1976: Distribution of selected metals in tissue samples of carp, Cyprinus carpio. Bull Environ Contam Toxicol 15: 374-377

Seymore T, Du-Preez HH, Van-Vuren JHJ 1996: Concentrations of zinc in Barbus marequensis from the lower Olifants river, Mpumalanga, South Africa. Hydrobiologia 332: 141-150

Staniskiene B, Matusevicius P, Budreckiene R, Skibniewska KA 2006: Distribution of heavy metals in tissue of freshwater fish in Lithuania. Pol J Environ Stud 15: 585-591

Svobodová Z, Gelnarová J, Justýn J, Krupauer V, Máchová J, Simanov L, Valentová V, Vykusová B, Wohlgemuth E 1987: Toxikologie vodních živočichů (Toxicology of water animals). SZN Praha, 232 p.

Svobodová Z, Hejtmánek M, Studnicka M, Randák T 2004: Obsah rtuti ve svalovině hospodářsky významných druhů ryb na území ČR - přehled (Mercury content in muscle of economically important fish species in the Czech Republic - review). Veterinářství 12: 702-706

Svobodová Z, Máchová J, Vykusová B, Piačka V 1996: Kovy v ekosystémech povrchových vod (Metals in ecosystems of surface water). Methods RIFCH Vodňany 49: 18 p.

Svobodová Z, Žlábek V, Čelechovská O, Randák T, Máchová J, Kolářová J 2002: Content of metals in tissues of marketable common carp and in bottom sediments of selected ponds of South and West Bohemia. Czech J Anim Sci 47: 339-350

Tepe Y, Türkmen M, Türkmen A 2008: Assessment of heavy metals in two commercial fish species of four Turkish seas. Environ Monit Assess 146: 277-284

Velíšek J 2002: Chemie potravin 2 (Chemistry of foodstuffs 2). OSSIS, Tábor, 320 p.

WHO 1990: Methylmercury. In: Environmental health criteria 101. World Health Organisation, Geneva, pp. $1-145$ 